Letter to the Editor

\section{Fungal mutants not solved by internal amplification controls}

\section{Dear Sir or Madam}

I was interested to read Rodríguez et al. (2012) on PCR to detect verrucosin producing fungi in food and cultures. However, their interpretation regarding mutated strains and internal amplification controls (IAC) appears to be incorrect, although they referred to our papers on the issue. It is worth restating to the wider scientific community that fungi may be mutated by self produced mutagens and enzyme inhibitors leading to false negative or positive results (Paterson et al., 2008; Paterson and Lima 2009) for which an IAC is irrelevant. Finally, interpretations of PCR results from cultures or food require to consider these possibilities.

I look forward to your reply.

Yours faithfully

R Russell M Paterson

\section{References}

Paterson, R.R.M., Lima, N., 2009. Mutagens manufactured in fungal culture may affect DNA/RNA of producing fungi. Journal of Applied Microbiology 106, 1070-1080.

Paterson, R.R.M., Sariah, M., Lima, N., Zainal Abidin, M.A., Santos, C., 2008. Mutagenic and inhibitory compounds produced by fungi affect detrimentally diagnosis and phylogenetic analyses. Current Bioactive Compounds 4, 245-257.

Rodríguez A., Córdoba, J.J., Werning, M.L., Andrade, M.J., Rodríguez, M., 2012. Duplex real-time PCR method with internal amplification control for quantification of verrucosidin producing molds in dry-ripened foods. International Journal of Food Microbiology 153, 85-91.

R. Russell M. Paterson IBB-Institute for Biotechnology and Bioengineering Centre of Biological Engineering Campus de Gualtar

University of Minho 4710-057 Braga, Portugal

Corresponding author. Tel.: + 351253604 423;

fax: + 351253678986 .

E-mail address: russell.paterson@deb.uminho.pt.

21 December 2011 